\title{
Clinical Perspectives of Urocortin and Related Agents for the Treatment of Cardiovascular Disease
}

\author{
Keiichi Ikeda, ${ }^{1}$ Kouki Fujioka, ${ }^{1}$ Yoshinobu Manome, ${ }^{1}$ and Katsuyoshi Tojo ${ }^{2}$ \\ ${ }^{1}$ Department of Molecular Cell Biology, Institute of DNA Medicine, Research Center for Medical Sciences, \\ Jikei University School of Medicine, Tokyo 105-8461, Japan \\ ${ }^{2}$ Division of Diabetes and Endocrinology, Department of Internal Medicine, Jikei University School of Medicine, \\ Tokyo 105-8461, Japan \\ Correspondence should be addressed to Keiichi Ikeda, ikedak@jikei.ac.jp
}

Received 21 November 2011; Revised 7 February 2012; Accepted 7 February 2012

Academic Editor: Kazunori Kageyama

Copyright ( $) 2012$ Keiichi Ikeda et al. This is an open access article distributed under the Creative Commons Attribution License, which permits unrestricted use, distribution, and reproduction in any medium, provided the original work is properly cited.

\begin{abstract}
The effects of corticotropin-releasing hormone, also known as corticotropin-releasing factor (CRF), on the cardiovascular system have been intensively researched since its discovery. Moreover, the actions of urocortin (Ucn) I on the cardiovascular system have also been intensively scrutinized following the cloning and identification of its receptor, CRF receptor type 2 (CRFR2), in peripheral tissues including the heart. Given the cardioprotective actions of CRFR2 ligands, the clinical potential of not only Ucn I but also Ucn II and III, which were later identified as more specific ligands for CRFR2, has received considerable attention from researchers. In addition, recent work has indicated that CRF type 1 receptor may be also involved in cardioprotection against ischemic/reperfusion injury. Here we provide a historical overview of research on Ucn I and related agents, their effects on the cardiovascular system, and the clinical potential of the use of such agents to treat cardiovascular diseases.
\end{abstract}

\section{Introduction: Overview of Corticotropin-Releasing Hormone and Related Peptides and Their Effects on the Cardiovascular System}

Since the discovery of a 41-residue ovine hypothalamic peptide that stimulates secretion of corticotropin, several studies have revealed that corticotropin-releasing factor (CRF) affects the cardiovascular system, although the CRF receptors involved in this process had not been identified [1-9]. In 1995, a major breakthrough in research on the effects of CRF-related peptides on the cardiovascular system took place with the cloning and identification of the CRF type 2 receptor (CRFR2) in peripheral tissues including the cardiovascular system [10-14]. This finding indicated that CRF and related peptides may affect the heart and vascular tissues. In addition, urocortin (Ucn) I, which was later recognized as a key CRF peptide in the heart, was also identified in rat mid brain tissue [15], while Ucn I mRNA, but not CRF, was identified in cardiomyocytes [16]. Several studies revealed that stimulation of CRFR2 by CRF and Ucn I induced the release of atrial and brain natriuretic peptides (ANP and BNP, resp.) [17, 18], which are used as the indicators of cardiac hypertrophy [19] and, in another hand, have an antihypertrophic action [20], had a positive inotropic action on the heart [21], increased protein and DNA synthesis in cardiac fibroblasts [18, 22, 23], and exerted a cardioprotective action against hypoxia $[16,24$, 25]. Ucn I immunoreactivity has also been identified in normal and diseased human heart, especially in the hearts of patients with dilated and hypertrophic cardiomyopathies (DCM and HCM, resp.) [22, 26, 27]. The other reported beneficial actions of Ucn I on the heart is to reduce infarct size in vivo, improve intracellular calcium handling [28], increase the ventricular fibrillation threshold [29], reduce the occurrence of arrhythmias [28], and inhibit efferent cardiac sympathetic nerve activity [30]. These facts indicated that Ucn I and its analogs may have beneficial actions in the treatment of cardiac diseases as well as play certain roles in cardiac diseases. Furthermore, CRFR2, which is a potential receptor of Ucns in the heart, may play an important role in adaptation to cardiac stress [31], and dominant negative 
effects of a recently identified variant isoform of CRFR2 may play a critical role in the pathophysiology of stressinduced heart disease [32]. These findings indicate that CRFR2 signaling is important in the adaptation to cardiac stress and heart-related diseases. In addition to Ucn I, the Ucn I analogs Ucn II and Ucn III, which are more specific ligands of CRFR2, were successively identified in searches of publicly available human genome databases $[33,34]$. Ucn II and Ucn III were also identified in human and rodent heart [35-37]. Thereafter, more studies on the effects of Ucn I and related peptides were undertaken.

CRFR2 was also identified in the aorta-derived A7R5 cell line [38], and Ucn I was identified in human umbilical vein endothelial cells (HUVECs) [39]. Ucn I and its analogs exert vasodilatory effects in arteries and veins via their action on CRFR2 [40-42]. Furthermore, Ucn I exerts an antioxidative action in response to the angiotensin II-induced generation of reactive oxygen species (ROS) by HUVECs [39]. In other studies, however, Ucn I was shown to exert proinflammatory effects by augmenting via CRFR2 the lipopolysaccharideinduced expression of cyclooxygenase (COX)-2 and intercellular adhesion molecule-1 in rat aortic endothelial cells and to induce vasculitis via CRF type 1 receptor (CRFR1) $[43,44]$.

\section{CRFR1 and CRFR2 Signaling in the Cardiovascular System and Cardioprotective Action of Ucns}

Several studies have described the signal transduction pathway for CRFR2. Recently, the CRFR1 was identified in HL1 cardiomyocytes in addition to CRFR2, and the possible involvement of CRFR1-mediated extracellularly regulated kinase1/2 (ERK1/2) signaling pathways in Ucns' cardioprotective action against ischemia/reperfusion injury was indicated [45]. It has been suggested that the CRFR1 and CRFR2 signal transduction pathways in cardiovascular cells involve protein kinase A (PKA) [18, 35, 40], Src [45], p38 mitogenactivated kinases (MAPKs) [40, 46], ERK1/2 [45, 47-49], the protein kinase $\mathrm{C}(\mathrm{PKC})$ pathway $[50,51]$, the protein kinase B/Akt pathway [36, 48, 49], phosphoinositide-3 kinase (PI3K) [49], the COX-2 pathway [52], and the endothelial nitric oxide synthase pathway [48]. For example, the hypertrophyinducing action of Ucns, which is manifested by an increase of ANP and BNP secretion from cardiomyocytes and an increase in protein synthesis, may be induced via the PKA and Akt pathways $[18,35,36]$, while the cardioprotective action of Ucns against hypoxia and reperfusion injury may involve the Src, ERK1/2, PKC, and PI3-K pathways [45, 49, 51].

\section{Clinical Use of Ucns to Treat Cardiovascular Disease}

Some clinical applications of Ucns in cardiovascular diseases, such as ischemic heart disease, cardiac failure, and hypertension, among others, have been proposed.
3.1. Ischemic Heart Disease. The relationship between the action of CRFR2 and ischemia-induced cardiomyocyte damage has been extensively investigated $[16,24,25,36,53]$. Ucn I clearly exerts an anti-ischemic action on cardiomyocytes. The protective action of Ucns against ischemia could be mediated via CRFR2 and, in turn, via the ERK1/2, MAPK, and PI3-K pathways $[24,53]$. In addition, pretreatment with Ucn I to protect against ischemia resulted in the significant recovery of high-energy phosphate pools [25]. The recent study suggested the expression of CRFR1 and possible involvement of the CRFR1 signaling pathway in cardioprotection against ischemic/reperfusion injury [45]. These findings indicate that Ucns and related agents (i.e., CRFR1 and CRFR2 agonists) could serve as candidate therapeutic agents to combat ischemic heart diseases.

3.2. Heart Failure. Elevated immunoreactivity to Ucn I in diseased heart was identified in DCM [22]. Our group also detected increased Ucn I immunoreactivity in the heart of DCM and HCM patients [27]. Furthermore, several studies reported that plasma Ucn I immunoreactivity was elevated in patients with cardiac failure and ischemic heart disease and in sheep with experimental cardiac failure [54-58]. Elevated plasma Ucn I concentrations combined with Nterminal proBNP may enhance prognostic performance in acute myocardial infarction [56]. On the other hand, several trials in which Ucns are being used to treat experimental [5964] and human cardiac failure [65] are ongoing and have provided some potentially beneficial results, because Ucn I may exert inotropic actions that may play a key role in the treatment of cardiac failure. And Ucn II may also improve the renal function [66], and sympathetic activity in heart failure [30], synthetic Ucns, or nonpeptide CRF receptor agonists may prove useful for the treatment of cardiac failure.

3.3. Hypertension. One of the actions of Ucns on the vasculature is to cause vasodilation. In addition to these vasodilatory actions, Yang et al. suggested that Ucn I may decrease the activity of angiotensin-converting enzyme and, in turn, reduce blood pressure $[67,68]$. To this extent, infusion of Ucn II in healthy humans and in patients with cardiac failure resulted in a decrease of blood pressure [65, 69]. However, clinical data on the treatment of hypertension with Ucns are not yet available.

In conclusion, Ucn-related agents (synthetic CRF receptor agonists) may have clinical potential for the treatment of patients with clinically manifested cardiovascular diseases. Accumulating evidence of the beneficial actions of Ucns will serve as the experimental basis for the clinical use of Ucnrelated compounds.

\section{References}

[1] M. Grunt, J. Glaser, H. Schmidhuber, P. Pauschinger, and J. Born, "Effects of corticotropin-releasing factor on isolated rat heart activity," American Journal of Physiology, vol. 264, no. 4, pp. H1124-H1129, 1993. 
[2] M. Grunt, C. Haug, L. Duntas, P. Pauschinger, V. Maier, and E. F. Pfeiffer, "Dilatory and inotropic effects of corticotropinreleasing factor (CRF) on the isolated heart. Effects on atrial natriuretic peptide (ANP) release," Hormone and Metabolic Research, vol. 24, no. 2, pp. 56-59, 1992.

[3] L. A. Fisher, J. Rivier, C. Rivier, J. Spiess, W. Vale, and M. R. Brown, "Corticotropin-releasing factor (CRF): central effects on mean arterial pressure and heart rate in rats," Endocrinology, vol. 110, no. 6, pp. 2222-2224, 1982.

[4] L. A. Fisher, G. Jessen, and M. R. Brown, "Corticotropinreleasing factor (CRF): mechanism to elevate mean arterial pressure and heart rate," Regulatory Peptides, vol. 5, no. 2, pp. 153-161, 1983.

[5] J. G. Kiang and E. T. Wei, "CRF-evoked bradycardia in urethane-anesthetized rats is blocked by naloxone," Peptides, vol. 6, no. 3, pp. 409-413, 1985.

[6] W. Vale, J. Spiess, C. Rivier, and J. Rivier, "Characterization of a 41-residue ovine hypothalamic peptide that stimulates secretion of corticotropin and $\beta$-endorphin," Science, vol. 213, no. 4514, pp. 1394-1397, 1981.

[7] A. R. Hermus, G. F. Pieters, J. J. Willemsen et al., "Hypotensive effects of ovine and human corticotrophin-releasing factors in man," European Journal of Clinical Pharmacology, vol. 31, no. 5, pp. 531-534, 1987.

[8] M. Saitoh, J. Hasegawa, and H. Mashiba, "Effect of corticotropin-releasing factor on the electrical and mechanical activities of the guinea-pig ventricular myocardium," General Pharmacology, vol. 21, no. 3, pp. 337-342, 1990.

[9] C. Haug, M. Grunt, S. Schmid et al., "Effect of corticotropin releasing factor on atrial natriuretic peptide release from the isolated perfused rat heart," Arzneimittel-Forschung, vol. 44, no. 5, pp. 579-582, 1994.

[10] T. W. Lovenberg, D. T. Chalmers, C. Liu, and E. B. De Souza, "CRF $2 \alpha$ and CRF $2 \beta$ receptor mRNAs are differentially distributed between the rat central nervous system and peripheral tissues," Endocrinology, vol. 136, no. 9, pp. 41394142, 1995.

[11] T. W. Lovenberg, C. W. Liaw, D. E. Grigoriadis et al., "Cloning and characterization of a functionally distinct corticotropinreleasing factor receptor subtype from rat brain," Proceedings of the National Academy of Sciences of the United States of America, vol. 92, no. 3, pp. 836-840, 1995.

[12] P. Stenzel, R. Kesterson, W. Yeung, R. D. Cone, M. B. Rittenberg, and M. P. Stenzel-Poore, "Identification of a novel murine receptor for corticotropin-releasing hormone expressed in the heart," Molecular Endocrinology, vol. 9, no. 5, pp. 637-645, 1995.

[13] T. Kishimoto, R. V. Pearse II, C. R. Lin, and M. G. Rosenfeld, "A sauvagine/corticotropin-releasing factor receptor expressed in heart and skeletal muscle," Proceedings of the National Academy of Sciences of the United States of America, vol. 92, no. 4, pp. 1108-1112, 1995.

[14] M. Perrin, C. Donaldson, R. Chen et al., "Identification of a second corticotropin-releasing factor receptor gene and characterization of a cDNA expressed in heart," Proceedings of the National Academy of Sciences of the United States of America, vol. 92, no. 7, pp. 2969-2973, 1995.

[15] J. Vauhan, C. Donaldson, J. Bittencourt et al., "Urocortin, a mammalian neuropeptide related to fish urotensin I and to corticotropin-releasing factor," Nature, vol. 378, no. 6554, pp. 287-292, 1995.

[16] A. Okosi, B. K. Brar, M. Chan et al., "Expression and protective effects of urocortin in cardiac myocytes," Neuropeptides, vol. 32, no. 2, pp. 167-171, 1998.
[17] K. Tojo, S. Sato, G. Tokudome et al., "Stimulation by corticotropin-releasing factor of atrial natriuretic peptide and brain natriuretic peptide secretions from cultured neonatal rat cardiomyocytes," Biochemical and Biophysical Research Communications, vol. 225, no. 2, pp. 340-346, 1996.

[18] K. Ikeda, K. Tojo, S. Sato et al., "Urocortin, a newly identified corticotropin-releasing factor-related mammalian peptide, stimulates atrial natriuretic peptide and brain natriuretic peptide secretions from neonatal rat cardiomyocytes," Biochemical and Biophysical Research Communications, vol. 250, no. 2, pp. 298-304, 1998.

[19] V. A. Cameron and L. J. Ellmers, "Minireview: natriuretic peptides during development of the fetal heart and circulation," Endocrinology, vol. 144, no. 6, pp. 2191-2194, 2003.

[20] S. Kasama, M. Furuya, T. Toyama, S. Ichikawa, and M. Kurabayashi, "Effect of atrial natriuretic peptide on left ventricular remodelling in patients with acute myocardial infarction," European Heart Journal, vol. 29, no. 12, pp. 14851494, 2008.

[21] D. G. Parkes, J. Vaughan, J. Rivier, W. Vale, and C. N. May, "Cardiac inotropic actions of urocortin in conscious sheep," American Journal of Physiology, vol. 272, no. 5, pp. H2115H2122, 1997.

[22] T. Nishikimi, A. Miyata, T. Horio et al., "Urocortin, a member of the corticotropin-releasing factor family, in normal and diseased heart," American Journal of Physiology, vol. 279, no. 6, pp. H3031-H3039, 2000.

[23] K. Ikeda, K. Tojo, Y. Oki, and K. Nakao, "Urocortin has cellproliferative effects on cardiac non-myocytes," Life Sciences, vol. 71, no. 16, pp. 1929-1938, 2002.

[24] B. K. Brar, A. K. Jonassen, A. Stephanou et al., "Urocortin protects against ischemic and reperfusion injury via a MAPKdependent pathway," The Journal of Biological Chemistry, vol. 275, no. 12, pp. 8508-8514, 2000.

[25] T. M. Scarabelli, E. Pasini, A. Stephanou et al., "Urocortin promotes hemodynamic and bioenergetic recovery and improves cell survival in the isolated rat heart exposed to ischemia/reperfusion," Journal of the American College of Cardiology, vol. 40, no. 1, pp. 155-161, 2002.

[26] Y. Kimura, K. Takahashi, K. Totsune et al., "Expression of urocortin and corticotropin-releasing factor receptor subtypes in the human heart," Journal of Clinical Endocrinology and Metabolism, vol. 87, no. 1, pp. 340-346, 2002.

[27] K. Ikeda, K. Tojo, G. Tokudome et al., "Cardiac expression of urocortin (Ucn) in diseased heart; preliminary results on possible involvement of Ucn in pathophysiology of cardiac diseases," Molecular and Cellular Biochemistry, vol. 252, no. 12, pp. 25-32, 2003.

[28] C. N. Liu, C. Yang, X. Y. Liu, and S. Li, "In vivo protective effects of urocortin on ischemia-reperfusion injury in rat heart via free radical mechanisms," Canadian Journal of Physiology and Pharmacology, vol. 83, no. 6, pp. 459-465, 2005.

[29] S. Meili-Butz, K. Bühler, D. John et al., "Acute effects of urocortin 2 on cardiac function and propensity for arrhythmias in an animal model of hypertension-induced left ventricular hypertrophy and heart failure," European Journal of Heart Failure, vol. 12, no. 8, pp. 797-804, 2010.

[30] C. J. Charles, D. L. Jardine, M. T. Rademaker, and A. M. Richards, "Urocortin 2 induces potent long-lasting inhibition of cardiac sympathetic drive despite baroreflex activation in conscious sheep," Journal of Endocrinology, vol. 204, no. 2, pp. $181-189,2010$.

[31] S. C. Coste, R. A. Kesterson, K. A. Heldwein et al., "Abnormal adaptations to stress and impaired cardiovascular function 
in mice lacking corticotropin-releasing hormone receptor-2," Nature Genetics, vol. 24, no. 4, pp. 403-409, 2000.

[32] Y. Sztainberg, Y. Kuperman, O. Issler et al., "A novel corticotropin-releasing factor receptor splice variant exhibits dominant negative activity: a putative link to stress-induced heart disease," The FASEB Journal, vol. 23, no. 7, pp. 21862196, 2009.

[33] T. M. Reyes, K. Lewis, M. H. Perrin et al., "Urocortin II: a member of the corticotropin-releasing factor (CRF) neuropeptide family that is selectively bound by type $2 \mathrm{CRF}$ receptors," Proceedings of the National Academy of Sciences of the United States of America, vol. 98, no. 5, pp. 2843-2848, 2001.

[34] K. Lewis, C. Li, M. H. Perrin et al., "Identification of urocortin III, an additional member of the corticotropin-releasing factor (CRF) family with high affinity for the CRF2 receptor," Proceedings of the National Academy of Sciences of the United States of America, vol. 98, no. 13, pp. 7570-7575, 2001.

[35] K. Ikeda, K. Tojo, C. Otsubo et al., "Effects of urocortin II on neonatal rat cardiac myocytes and non-myocytes," Peptides, vol. 26, no. 12, pp. 2473-2481, 2005.

[36] A. Chanalaris, K. M. Lawrence, A. Stephanou et al., "Protective effects of the urocortin homologues stresscopin (SCP) and stresscopin-related peptide (SRP) against hypoxia/ reoxygenation injury in rat neonatal cardiomyocytes," Journal of Molecular and Cellular Cardiology, vol. 35, no. 10, pp. 12951305, 2003.

[37] K. Takahashi, K. Totsune, O. Murakami et al., "Expression of urocortin III/stresscopin in human heart and kidney," Journal of Clinical Endocrinology and Metabolism, vol. 89, no. 4, pp. 1897-1903, 2004.

[38] K. Kageyama, G. E. Gaudriault, M. J. Bradbury, and W. W. Vale, "Regulation of corticotropin-releasing factor receptor type $2 \beta$ messenger ribonucleic acid in the rat cardiovascular system by urocortin, glucocorticoids, and cytokines," Endocrinology, vol. 141, no. 7, pp. 2285-2293, 2000.

[39] T. Honjo, N. Inoue, R. Shiraki et al., "Endothelial urocortin has potent antioxidative properties and is upregulated by inflammatory cytokines and pitavastatin," Journal of Vascular Research, vol. 43, no. 2, pp. 131-138, 2006.

[40] K. Kageyama, K. Furukawa, I. Miki, K. Terui, S. Motomura, and T. Suda, "Vasodilative effects of urocortin II via protein kinase $\mathrm{A}$ and a mitogen-activated protein kinase in rat thoracic aorta," Journal of Cardiovascular Pharmacology, vol. 42, no. 4, pp. 561-565, 2003.

[41] E. Sanz, N. Fernández, L. Monge, B. Climent, G. Diéguez, and A. L. García-Villalón, "Relaxation of rat arteries by urocortin: effects of gender and diabetes," Journal of Pharmacy and Pharmacology, vol. 55, no. 6, pp. 783-788, 2003.

[42] E. Sanz, L. Monge, N. Fernández et al., "Relaxation by urocortin of human saphenous veins," British Journal of Pharmacology, vol. 136, no. 1, pp. 90-94, 2002.

[43] Y. Xu, R. Zhang, J. Chen et al., "Urocortin promotes the development of vasculitis in a rat model of thromboangiitis obliterans via corticotrophin-releasing factor type 1 receptors," British Journal of Pharmacology, vol. 157, no. 8, pp. 1368-1379, 2009.

[44] R. Zhang, Y. Xu, H. Fu, J. Wang, L. Jin, and S. Li, "Urocortin induced expression of COX-2 and ICAM-1 via corticotrophinreleasing factor type 2 receptor in rat aortic endothelial cells," British Journal of Pharmacology, vol. 158, no. 3, pp. 819-829, 2009.

[45] Z. Yuan, R. McCauley, C. Chen-Scarabelli et al., "Activation of Src protein tyrosine kinase plays an essential role in urocortin-mediated cardioprotection," Molecular and Cellular Endocrinology, vol. 325, no. 1-2, pp. 1-7, 2010.

[46] K. Kageyama and T. Suda, "Urocortin-related peptides increase interleukin-6 output via cyclic adenosine 5'-monophosphate-dependent pathways in A7r5 aortic smooth muscle cells," Endocrinology, vol. 144, no. 6, pp. 2234-2241, 2003.

[47] B. K. Brar, A. Chen, M. H. Perrin, and W. Vale, "Specificity and regulation of extracellularly regulated kinase $1 / 2$ phosphorylation through corticotropin-releasing factor (CRF) receptors 1 and $2 \beta$ by the CRF/urocortin family of peptides," Endocrinology, vol. 145, no. 4, pp. 1718-1729, 2004.

[48] E. Grossini, C. Molinari, D. A. Mary et al., "Urocortin II induces nitric oxide production through cAMP and $\mathrm{Ca}^{2+}$ related pathways in endothelial cells," Cellular Physiology and Biochemistry, vol. 23, no. 1-3, pp. 87-96, 2009.

[49] B. K. Brar, A. Stephanou, R. Knight, and D. Latchman, "Activation of protein kinase B/Akt by urocortin is essential for its ability to protect cardiac cells against hypoxia/reoxygenationinduced cell death," Journal of Molecular and Cellular Cardiology, vol. 34, no. 4, pp. 483-492, 2002.

[50] K. M. Lawrence, A. M. Kabir, M. Bellahcene et al., "Cardioprotection mediated by urocortin is dependent on $\mathrm{PKC} \varepsilon$ activation," The FASEB Journal, vol. 19, no. 7, pp. 831-833, 2005.

[51] P. A. Townsend, S. M. Davidson, S. J. Clarke et al., "Urocortin prevents mitochondrial permeability transition in response to reperfusion injury indirectly by reducing oxidative stress," American Journal of Physiology, vol. 293, no. 2, pp. H928H938, 2007.

[52] K. Kageyama, K. Hanada, T. Nigawara et al., "Urocortin induces interleukin-6 gene expression via cyclooxygenase-2 activity in aortic smooth muscle cells," Endocrinology, vol. 147, no. 9, pp. 4454-4462, 2006.

[53] B. K. Brar, A. K. Jonassen, E. M. Egorina et al., "UrocortinII and urocortin-III are cardioprotective against ischemia reperfusion injury: an essential endogenous cardioprotective role for corticotropin releasing factor receptor Type 2 in the murine heart," Endocrinology, vol. 145, no. 1, pp. 24-35, 2004.

[54] L. L. Ng, I. W. Loke, R. J. O’Brien, I. B. Squire, and J. E. Davies, "Plasma urocortin in human systolic heart failure," Clinical Science, vol. 106, no. 4, pp. 383-388, 2004.

[55] W. H. Wilson Tang, W. Tong, K. Shrestha et al., "Differential effects of arginine methylation on diastolic dysfunction and disease progression in patients with chronic systolic heart failure," European Heart Journal, vol. 29, no. 20, pp. 25062513, 2008.

[56] A. Phrommintikul, S. Sivasinprasasn, N. Lailerd, S. Chattipakorn, S. Kuanprasert, and N. Chattipakorn, "Plasma urocortin in acute myocardial infarction patients," European Journal of Clinical Investigation, vol. 40, no. 10, pp. 874-882, 2010.

[57] C. J. Charles, M. T. Rademaker, A. M. Richards, and T. G. Yandle, "Plasma urocortin 1 in sheep: regional sampling and effects of experimental heart failure," Peptides, vol. 27, no. 7, pp. 1801-1805, 2006.

[58] S. P. Wright, R. N. Doughty, C. M. Frampton, G. D. Gamble, T. G. Yandle, and A. M. Richards, "Plasma urocortin 1 in human heart failure," Circulation, vol. 2, no. 5, pp. 465-471, 2009.

[59] M. T. Rademaker, C. J. Charles, E. A. Espiner et al., "Beneficial hemodynamic, endocrine, and renal effects of urocortin in experimental heart failure: comparison with normal sheep," Journal of the American College of Cardiology, vol. 40, no. 8, pp. 1495-1505, 2002. 
[60] T. L. Bale, M. Hoshijima, Y. Gu et al., "The cardiovascular physiologic actions of urocortin II: acute effects in murine heart failure," Proceedings of the National Academy of Sciences of the United States of America, vol. 101, no. 10, pp. 3697-3702, 2004.

[61] M. T. Rademaker, C. J. Charles, E. A. Espiner, C. M. Frampton, J. G. Lainchbury, and A. M. Richards, "Four-day urocortinI administration has sustained beneficial haemodynamic, hormonal, and renal effects in experimental heart failure," European Heart Journal, vol. 26, no. 19, pp. 2055-2062, 2005.

[62] M. T. Rademaker, V. A. Cameron, C. J. Charles, and A. M. Richards, "Integrated hemodynamic, hormonal, and renal actions of urocortin 2 in normal and paced sheep: beneficial effects in heart failure," Circulation, vol. 112, no. 23, pp. 36243632, 2005.

[63] M. T. Rademaker, V. A. Cameron, C. J. Charles, and A. M. Richards, "Urocortin 3: haemodynamic, hormonal, and renal effects in experimental heart failure," European Heart Journal, vol. 27, no. 17, pp. 2088-2098, 2006.

[64] M. T. Rademaker, C. J. Charles, and A. M. Richards, "Urocortin 1 administration from onset of rapid left ventricular pacing represses progression to overt heart failure," American Journal of Physiology, vol. 293, no. 3, pp. H1536-H1544, 2007.

[65] M. E. Davis, C. J. Pemberton, T. G. Yandle et al., "Urocortin 2 infusion in human heart failure," European Heart Journal, vol. 28, no. 21, pp. 2589-2597, 2007.

[66] M. T. Rademaker, C. J. Charles, M. G. Nicholls, and A. M. Richards, "Urocortin 2 inhibits furosemide-induced activation of renin and enhances renal function and diuretic responsiveness in experimental heart failure," Circulation, vol. 2, no. 6, pp. 532-540, 2009.

[67] C. Yang, Y. Xu, T. Mendez, F. Wang, Q. Yang, and S. Li, "Effects of intravenous urocortin on angiotensin-converting enzyme in rats," Vascular Pharmacology, vol. 44, no. 4, pp. 238-246, 2006.

[68] C. Yang, X. Liu, and S. Li, "Effect of long-term treatment with urocortin on the activity of somatic angiotensin-converting enzyme in spontaneously hypertensive rats," Canadian Journal of Physiology and Pharmacology, vol. 88, no. 2, pp. 168-176, 2010.

[69] M. E. Davis, C. J. Pemberton, T. G. Yandle et al., "Urocortin 2 infusion in healthy humans. hemodynamic, neurohormonal, and renal responses," Journal of the American College of Cardiology, vol. 49, no. 4, pp. 461-471, 2007. 


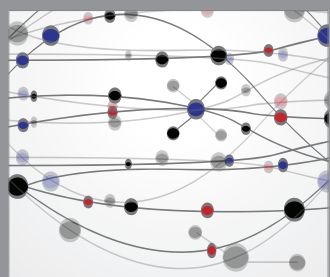

The Scientific World Journal
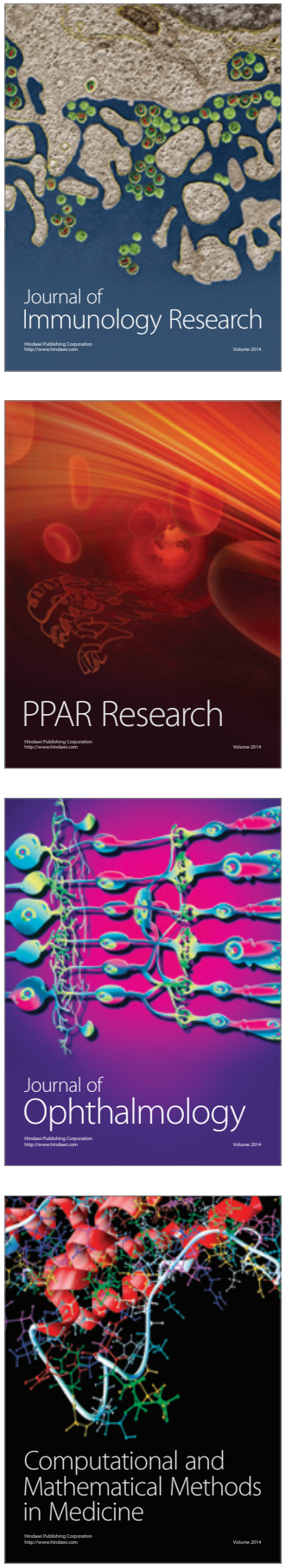

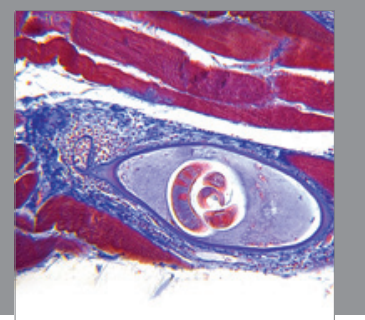

Gastroenterology

Research and Practice
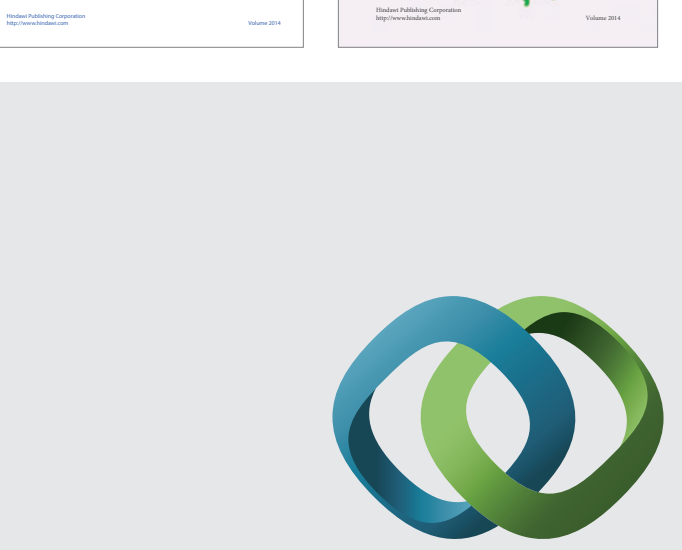

\section{Hindawi}

Submit your manuscripts at

http://www.hindawi.com
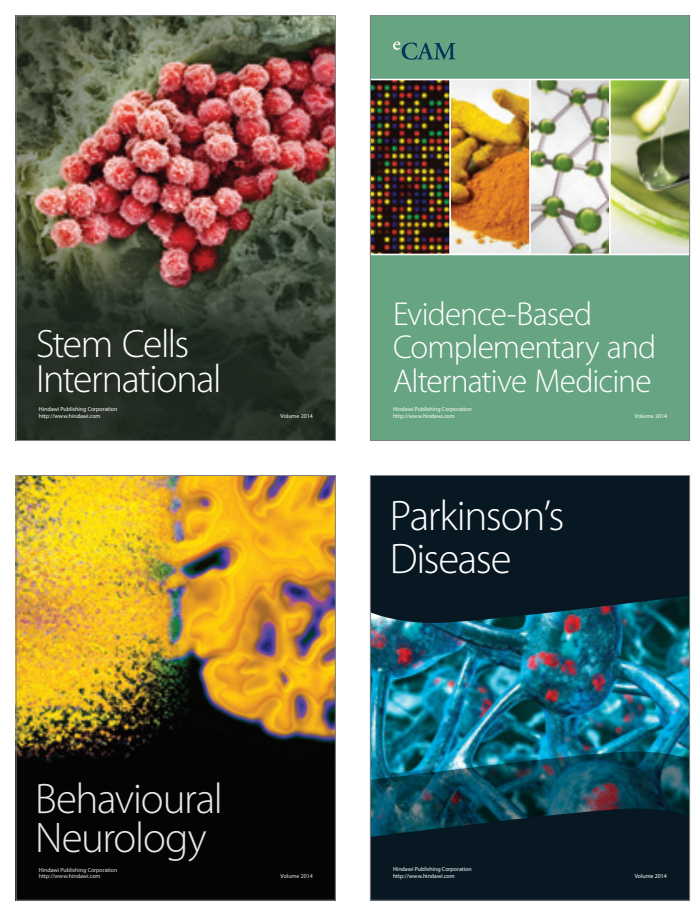

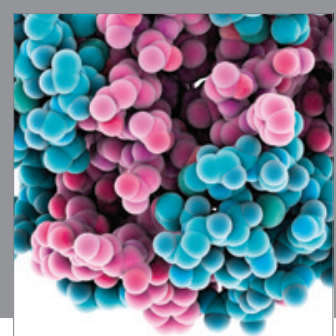

Journal of
Diabetes Research

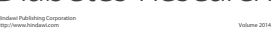

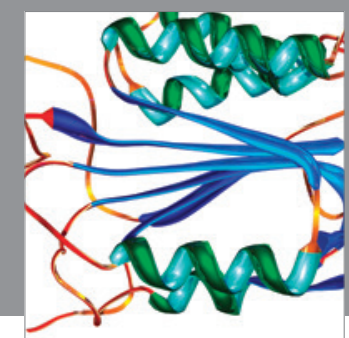

Disease Markers
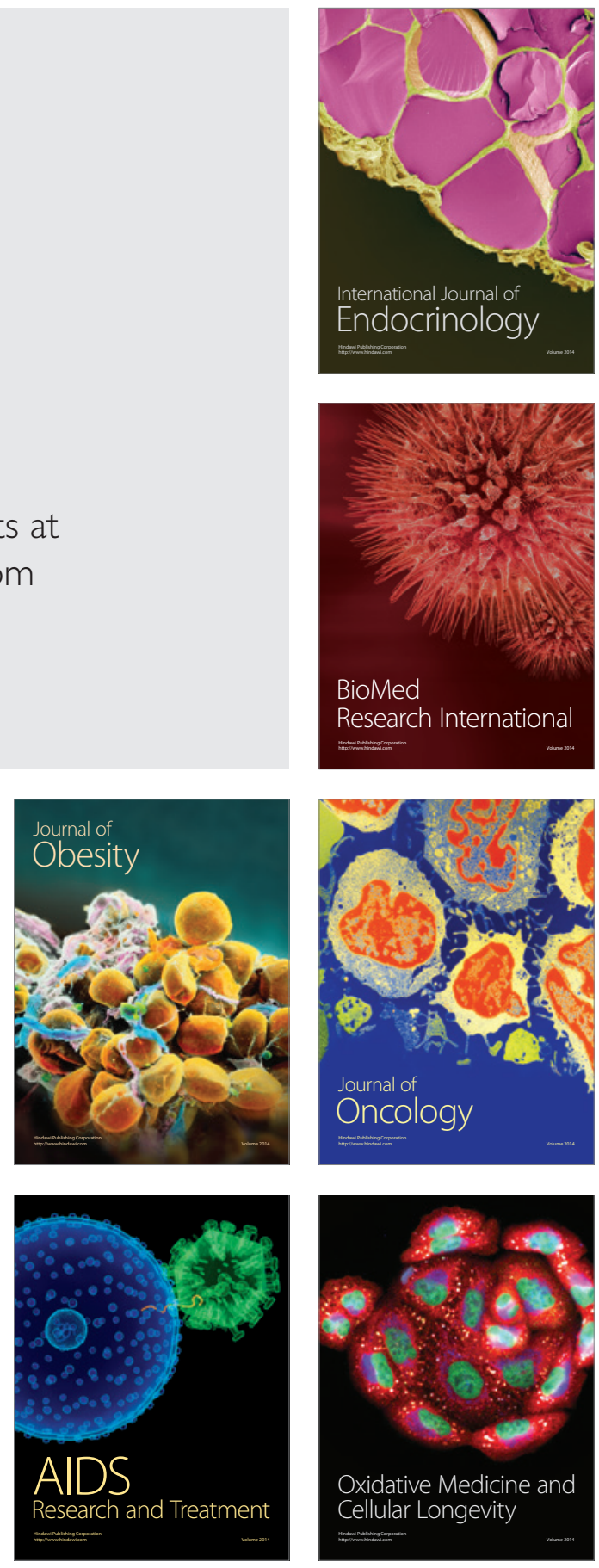